\title{
CADDISFLIES (INSECTA: TRICHOPTERA) FROM KOŽUF AND BABA MOUNTAINS (REPUBLIC OF NORTH MACEDONIA)
}

\section{Valentina Slavevska-Stamenkovićí ${ }^{1}$, Halil Ibrahimi ${ }^{2}$, Jelena Hinić ${ }^{1}$, Danijela Mitic-Kopanja ${ }^{1}$, Astrit Bilalli ${ }^{3}$, Milaim Musliu ${ }^{4}$, IOANNIS KaRAOUZAS ${ }^{5}$ \& MLADEN Kučinić 6}

${ }^{1}$ Institute of Biology, Faculty of Natural Sciences and Mathematics, Gazi Baba bb, 1000 Skopje, North Macedonia (E-mails: vstamen@yahoo.com; jelenahinikj@gmail.com; mitickopanja@yahoo.com)

${ }^{2}$ Department of Biology, Faculty of Mathematical and Natural Sciences, University of Prishtina, "Mother Theresa"street p.n., 10000 Prishtina, Republic of Kosovo (E-mail: halilibrahimi@yahoo.com)

${ }^{3}$ Faculty of Agribusiness, University of Peja "Haxhi Zeka", "UÇK"street, 30000 Pejë, Republic of Kosovo (E-mail: astritbilalli@yahoo.com)

${ }^{4}$ Institute for Environment and Health, Faculty of Contemporary Sciences and Technologies, South East European University, Ilindenska 335, 1200 Tetovo, North Macedonia (E-mail: milaim.musliu@yahoo.com)

${ }^{5}$ Institute of Marine Biological Resources and Inland Waters, Hellenic Centre for Marine Research, 46.7 km Athens-Sounio Av., Anavyssos 19013, Greece (E-mail: ikarz@hcmr.gr)

${ }^{6}$ Department of Biology, Faculty of Science, University of Zagreb, Rooseveltovtrg 6, 10000 Zagreb, Croatia (E-mail: kucinic@biol.pmf.hr)

Slavevska-Stamenković, V., Ibrahimi, H., Hinić, J., Mitic-Kopanja, D., Bilalli, A., Musliu, M., Karaouzas, I. \& Kučinić, M.: Caddisflies (Insecta: Trichoptera) from Kožuf and Baba mountains (Republic of North Macedonia. Nat. Croat., Vol. 30, No. 1, 145-160, 2021, Zagreb.

Adult caddisflies were collected during 2018 and 2019 from Kožuf and Baba mountains, located in the southern end of the Republic of North Macedonia. A total of 36 species were recorded, of which 22 and 8 were recorded for the first time for Kožuf and Baba mountains, respectively. Limnephilus flavicornis (Fabricius, 1787) is reported for the first time from the country from Kožuf Mountain. In addition, new localities of several rare and endemic caddisfly species were found. The results of this study highlight Kožuf and Baba mountains as refugium for caddisfly species of conservation importance.

Key words: rare species, endemic species, diversity, distribution, R. North Macedonia

Slavevska-Stamenković, V., Ibrahimi, H., Hinić, J., Mitic-Kopanja, D., Bilalli, A., Musliu, M., Karaouzas, I. \& Kučinić, M.: Tulari (Insecta: Trichoptera) planine Kožufa i Babe (Republika Sjeverna Makedonija. Nat. Croat., Vol. 30, No. 1, 145-160, 2021, Zagreb.

Tijekom 2018 i 2019 prikupljani su odrasli tulari na planinama Kožuf i Baba, smještenim na južnom dijelu Republike Sjeverne Makedonije. Zabilježeno je 36 vrsta, od kojih su 22, odnosno njih 8, po prvi puta za planine Kožuf, odnosno Baba. Limnephilus flavicornis (Fabricius, 1787) zabilježena je prvi puta za Sjevernu Makedoniju, na planini Kožuf. Nađeni su i novi lokaliteti za nekoliko rijetkih i endemičnih vrsta. Rezultati ovog istraživanja ističu planine Kožuf i Baba kao refugije za vrste tulara važnih za zaštitu. donija

Ključne riječi: rijetke vrste, endemi, raznolikost, rasprostranjenost, Republika Sjeverna Make- 


\section{INTRODUCTION}

Compared to mayflies and stoneflies, the caddisfly fauna of the Republic of North Macedonia has never been in the focus of continuous research and thus the diversity and distribution of this aquatic insect order still remain poorly known (SLAvevsKa-Stamenković et al., 2016). The first caddisfly data of the R. of North Macedonia were published over eighty years ago, when RADOVANOvić (1935) registered 6 species for the country. In his next paper on the Trichoptera from Ohrid Lake and its surroundings (Jablanica and Pelister) Radovanović (1943) gave information about the presence of 43 species, of which only Limnephilus rhombicus (Linnaeus, 1758) and Mystacides longicornis (Linnaeus, 1758) had previously been reported. The next investigation into adult caddisflies was conducted by BotoşĂneanu (1960) on Mt Pelister and nearby Ohrid Lake (Shum, St. Naum Springs). Later, PAVlovski $(1984,1991)$ and Arsov (1991) made an inventory of caddisfly larvae and adults from the rivers Zrnovska and Babuna, while Kumanski (1997) and Kumanski \& Malicky (1999) reported new faunistic data on Trichoptera from the country.

Considerable progress has been made in recent year, when some areas became much better explored (OцÁH 2010, 2011; OláH et al., 2013a, 2013b, 2014, 2015, 2018, 2019; OlÁH \& KovÁcs 2013, 2014; KuČInić et al., 2016; Vitecé et al., 2015a, 2015b, 2015c; Waringer et al., 2015; Rimcheska et al., 2015; SLavevska-Stamenković et al., 2016; Bilalli et al., 2018, 2019). However, there are still parts of the country where only scarce data is available, such as Baba (Botoşăneanu 1960; OláH 2010; OláH \& Kovács 2013; OlÁH et al., 2014, 2017, 2018, 2019; Previšić et al., 2014; RAdOVANOVIĆ, 1943; ŠAPKARev, 1997; Waringer et al., 2016) and Kožuf (OláH et al., 2013; OláH \& Kovács 2013, 2014; Previšić et al., 2014) mountains. These mountains are very important areas in terms of caddisfly fauna, and recent research resulted in the description of new species, such as Agaphyalax balcanicus Olah, Kovacs \& Ibrahimi, 2018 from Baba (OLÁH et al., 2018) and Chaetopteroides tunik Olah, 2013 from Kožuf mountain (OLÁH et al., 2013).

The aim of this study is to contribute to the faunistic list of caddisflies from Kožuf and Baba mountains (Republic of North Macedonia), to summarize literature and recent unpublished faunistic data and to provide information on the distribution of some rare and endemic species.

\section{MATERIALS AND METHODS}

\section{Study area}

Adult caddisflies were collected from ten localities in the Republic of North Macedonia (Fig. 1). The first four sampling sites are located on Kožuf Mountain (protected area within the Emerald network), where K1 (brook) and K4 (stream) are situated in the forest zone, while K2 (open brook) and K3 (small lake and open brooks) are located in the alpine grassland.

The rest of the sampling sites are located on Baba Mountain within Pelister National Park, a potential Natura 2000 site. Among them, sampling sites from B5 to B9 are situated in the forest zone, while B10 (tributary of Caparska Reka River) at the edge of the forest zone. All localities belong to the $6^{\text {th }}$ ecoregion (Hellenic Western Balkan) according to Illies (1978). Detailed information about the sampling localities of collected adult specimens are presented in Table 1. 


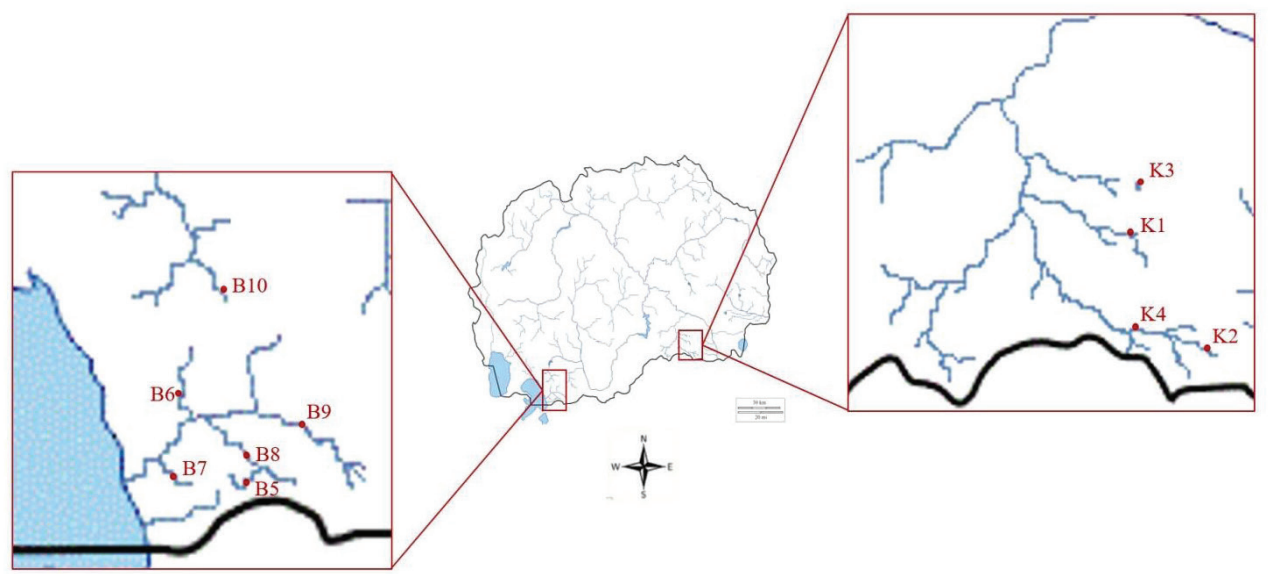

Fig. 1. Map of the sampling localities of Kožuf (K1 - K4) and Baba mountains (B5 - B10) (R. North Macedonia).
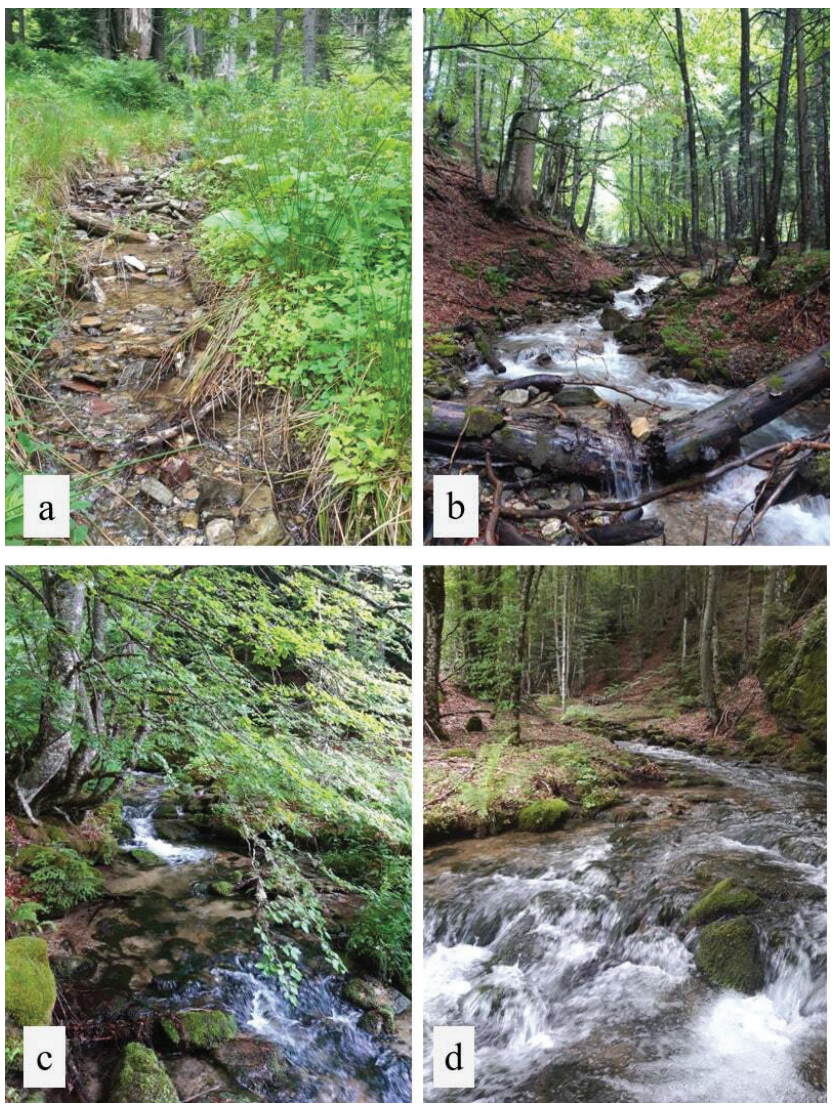

Fig. 2a-d. Sampling localities on Kožuf and Baba mountains (R. North Macedonia): a) K1 - Brook in the forest zone, b) K4 - Stream in the forest zone, c) B8 - Rzanska Reka River, d) B9 - Brajcinska Reka River above the intake of small hydro power plant (SHPP) Brajcino 1. 
Kožuf Mountain is situated between the Republic of North Macedonia and Greece. Its highest peak is Zelenbeg at $2171 \mathrm{~m}$ asl. Because this area is a natural barrier in the Republic of North Macedonia, directly exposed to the influences of the Mediterranean and the Aegean Sea, it is an important biodiversity hotspot for different groups of organisms in the country (STOJMILOV, 2011).

Baba Mountain, also known by the name of its highest peak, Pelister (2601 $\mathrm{m}$ asl.), is the third highest mountain in R. North Macedonia. In areas lower than 1,200 $\mathrm{m}$ the climate is basically moderate continental, but also expresses the influences of a mountain climate. The higher areas are characterized by a continental climate, and starting from $1,800 \mathrm{~m}$, one can easily feel the mountain climate. Above 2,400 $\mathrm{m}$ the mountain climate gains certain alpine characteristics, with an average temperature of 1.3 to $2.3^{\circ} \mathrm{C}$. Pelister National Park, situated on Baba Mountain (Stojmilov, 2011), is the oldest and second largest national park in the R. North Macedonia after Mavrovo, and is renowned for its many endemic plant and animal species.

Tab. 1. Characteristics of the sampling sites from the Kožuf and Baba mountains (Republic of North Macedonia).

\begin{tabular}{|c|c|c|c|c|c|c|}
\hline Code & River/Locality & $\begin{array}{l}\text { Altitude } \\
\qquad(\mathrm{m})\end{array}$ & Longitude $\left({ }^{\circ} \mathrm{N}\right)$ & $\begin{array}{l}\text { Latitude } \\
\qquad\left({ }^{\circ} \mathrm{E}\right)\end{array}$ & Ecoregion & $\begin{array}{l}\text { Sampling } \\
\text { period }\end{array}$ \\
\hline \multicolumn{7}{|c|}{ Kožuf Mountain } \\
\hline K1 & $\begin{array}{l}\text { Brook in the forest } \\
\text { zone }\end{array}$ & 1580 & 41.19572 & 22.20575 & 6 & $\begin{array}{c}\text { June - July } \\
2019\end{array}$ \\
\hline $\mathrm{K} 2$ & $\begin{array}{l}\text { Open brook in } \\
\text { alpine grassland }\end{array}$ & 1808 & 41.17148 & 22.20595 & 6 & $\begin{array}{c}\text { June - July } \\
2019\end{array}$ \\
\hline $\mathrm{K} 3$ & $\begin{array}{l}\text { Small lake and open } \\
\text { brooks in alpine } \\
\text { grassland }\end{array}$ & 1668 & 41.20955 & 22.221941 & 6 & $\begin{array}{c}\text { June - July } \\
2019\end{array}$ \\
\hline K4 & $\begin{array}{l}\text { Stream in the forest } \\
\text { zone }\end{array}$ & 1466 & 41.18328 & 22.19485 & 6 & $\begin{array}{c}\text { June - July } \\
2019\end{array}$ \\
\hline \multicolumn{7}{|c|}{ Baba Mountain } \\
\hline B5 & $\begin{array}{l}\text { Small brook on } \\
\text { Rzanska Reka River }\end{array}$ & 1425 & 40.9041192 & 21.2036355 & 6 & June 2019 \\
\hline B6 & $\begin{array}{l}\text { Stanisar Reka River } \\
\text { below the intake of } \\
\text { small hydro power } \\
\text { plant (SHPP) } \\
\text { Brajcino } 2\end{array}$ & 1136 & 40.9153988 & 21.1814784 & 6 & June 2019 \\
\hline B7 & $\begin{array}{l}\text { Baltanska Reka river } \\
\text { above v. Brajcino }\end{array}$ & 1124 & 40.903579 & 21.169998 & 6 & June 2019 \\
\hline B8 & Rzanska Reka River & 1388 & 40.90586 & 21.20454 & 6 & June 2019 \\
\hline B9 & $\begin{array}{l}\text { Brajcinska Reka } \\
\text { River above the } \\
\text { intake of small } \\
\text { hydro power plant } \\
\text { (SHPP) Brajcino } 1\end{array}$ & 1371 & 40.9198120 & 21.2205601 & 6 & June 2019 \\
\hline B10 & $\begin{array}{l}\text { Brook on the edge of } \\
\text { the forest zone }\end{array}$ & 1808 & 41.01436 & 21.17423 & 6 & May 2018 \\
\hline
\end{tabular}




\section{Data sampling and processing}

Adult caddisfly specimens were collected with entomological nets and handpicking during the day, as well as ultraviolet (UV) pyramid light traps during the night. Samplings were conducted in May 2018 and during the period of June to July 2019 at the localities from Kožuf Mountain, and on Baba Mountain during June 2019. The collected material was preserved in $96 \%$ ethanol.

Adult specimens were identified using a Nikon SMZ745 stereomicroscope with appropriate identification keys (Kumanski, 1985, 1988; Malicky, 2004). All specimens collected are deposited in the Macedonian National Collection of Invertebrates (MNCI) Skopje and in the Laboratory of Zoology at the Faculty of Natural and Mathematical Sciences in Prishtina. Systematic presentation was done according to Morse (2019).

New distributional records are presented in Material examined. Literature records are given only for the species recorded during our investigation and are cited in a shortened form including the respective reference, name of the watercourse or lake and adjacent settlement or mountain. Additional information may be found in original papers. New caddisfly species added to the fauna of Kožuf and Baba mountains, as well as of R. North Macedonia, are given in Notes.

\section{RESULTS}

During our investigation thirty-six taxa were recorded from Kožuf and Baba mountains, belonging to twelve families: Rhyacophilidae, Glossosomatidae, Philopotamidae, Hydropsychidae, Polycentropodidae, Brachycentridae, Limnephilidae, Uenoidae, Odontoceridae, Goeridae, Sericostomatidae and Beraidae. Among the families, the highest number of species was recorded within Limnephilidae (14 taxa) and Rhyacophilidae (9), while Polycentropodidae (3 species) and Glossosomatidae (2 species) were less diverse families. All other caddisfly families are represented with only one species each.

Female specimens of the genus Hydropsyche are identified only up to the generic level and thus, they were not taken into consideration for counting of the taxa recorded from Kožuf and Baba mountains.

Systematic list of caddisflies collected at ten sampling localities of Kožuf and Baba mountains (R. North Macedonia):

Family: RHYACOPHILIDAE Stephens, 1836

Genus: Rhyacophila Pictet, 1834

1. Rhyacophila armeniaca Guerin - Meneville, 1834

Material examined:

Kožuf: K4. 20. VII. 2019. 1 ふ, 19. VI. 2019. 1 お.

Note: new for Kožuf Mountain

2. Rhyacophila balcanica Radovanovič, 1953

Material examined:

Kožuf: K2. 20. VII. 2019. 1 ふ; K4. 20. VII. 2019. 8 ふふ, 19. VI. 2019. 1 ふ.

Note: new for Kožuf Mountain 
3. Rhyacophila fischeri Botosaneanu, 1957

Material examined:

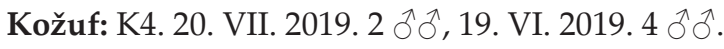

Note: new for Kožuf Mountain

4. Rhyacophila laevis Pictet, 1834

Material examined:

Baba: B5. 20. VI. 2019. 12 ઈิં.

Note: new for Baba Mountain

5. Rhyacophila loxias Schmid, 1970

Material examined:

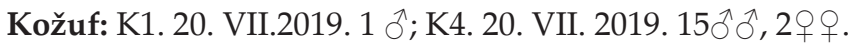

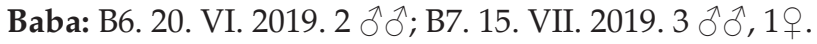

Note: new for Kožuf and Baba mountains

6. Rhyacophila nubila Zetterstedt, 1840

Material examined:

Baba: B6. 20. VI. 2019. 1 §.

Literature records:

Baba: OLÁH (2010): Noted near Brajcino Stream beneath Brajcino village.

7. Rhyacophila obtusa Klapalek, 1894

Material examined:

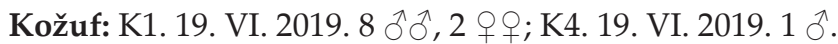

Note: new for Kožuf Mountain

8. Rhyacophila polonica McLachlan 1879

Material examined:

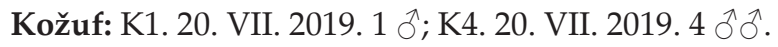

Note: new for Kožuf Mountain

9. Rhyacophila tristis Pictet, 1834

Mateiral examined:

Kožuf: K2. 20. VII. 2019. 1 ઈ.

Baba: B8. 20. VII. 2019. 1 ภ․

Literature records:

Baba: Botoşăneanu (1960): Medium sized stream in a valley towards Bitola and river at Capari village.

Note: new for Kožuf Mountain

Family: GLOSSOSOMATIDAE Wallengren, 1891

Genus: Glossosoma Curtis, 1834

10. Glossosoma conformis Neboiss, 1963

Material examined:

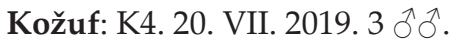

Note: new for Kožuf Mountain 
11. Glossosoma klotho Malicky, 2003

Material examined:

Kožuf: K4. 20. VII. 2019. 1 亍..

Note: new for Kožuf Mountain

Family: PHILOPOTAMIDAE Stephens, 1829

Genus: Philopotamus Stephens, 1829

12. Philopotamus montanus (Donovan, 1813)

Material examined:

Kožuf: K3. 20. VII. 2019. 8 ふึ, 4 q ; K4. 20. VII. 2019. 2 ふぇ, 1 q, 19. VI. 2019. 1 กิ.

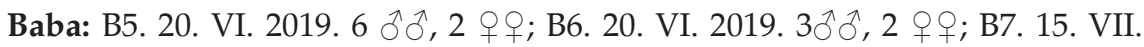
2019. 1 ぶ, 2 우; B8. 20. VII. 2019. 1 ふ, 4 우; B9. 19. VI. 2019. 2 ふぇ, 2 우.

Literature records:

Baba: BotoşĂneAnu (1960): River in Capari village.

Note: new for Kožuf Mountain

Family: HYDROPSYCHIDAE Curtis, 1835

Genus: Hydropsyche Picret, 1834

13. Hydropsyche incognita Pitsch, 1993

Material examined:

Baba: B6. 20. VI. 2019. 1 ð.

Note: new for Baba Mountain

Hydropsyche sp. females

Kožuf: K4. 20. VII. 2019. 1 \%.

Baba: B6. 20. VI. 2019. 1 ภ.

Family: POLYCENTROPODIDAE Ulmer, 1903

Genus: Plectrocnemia Stephens, 1836

14. Plectrocnemia brevis McLachlan, 1871

Material examined:

Kožuf: K4. 20. VII. 2019. 3ðð.

Note: new for Kožuf Mountain

15. Plectrocnemia conspersa (Curtis, 1834)

Material examined:

Kožuf: K3. 20. VII. 2019. 7 ふすં; K4. 20. VII. 2019. 1 ふ.

Note: new for Kožuf Mountain

Genus: Polycentropus Curtis, 1835

16. Polycentropus flavomaculatus (Pictet, 1834)

Material examined:

Baba: B6. 20. VI. 2019. 4ðึฎ.

Literature records:

Baba: Radovanović (1943): Registered in the upper part of Trnovska Reka river; RAdOvanović (1953): Collected from Pelister, without mention of the precise sampling site. 


\section{Family: BRACHYCENTRIDAE Ulmer, 1903}

\section{Genus: Brachycentrus Curtis, 1834}

17. Brachycentrus montanus Klapalek, 1892

Material examined:

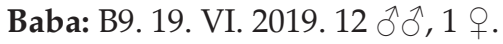

Note: new for Baba Mountain

\section{Family: LIMNEPHILIDAE Kolenati, 1848}

Genus: Drusus Stephens, 1837

18. Drusus biguttatus (Pictet, 1834)

Material examined:

Kožuf: K4. 19. VI. 2019.1 ठ.

Note: new for Kožuf Mountain

19. Drusus botosaneanui Kumanski, 1968

Material examined:

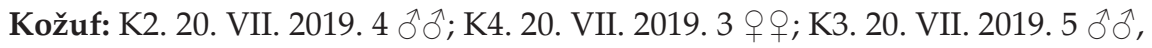
7 우오.

Note: new for Kožuf Mountain

20. Drusus discolor (Rambur, 1842)

Material examined:

Kožuf: K2. 20. VII. 2019. 2 ठో đ̋̄.

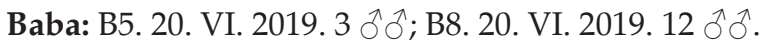

Literature records:

Kožuf: Previšić et al. (2014): Reported as larval stage without precise locality data.

Baba: BotoşăNeANu (1960): Medium sized stream on a valley towards Bitola; PREvišIć et al. (2014): Reported as larval stage without precise locality data; OlaH et al. (2017): Shiroka Hiking Lodge and on the way towards it.

21. Drusus sp.

Material examined:

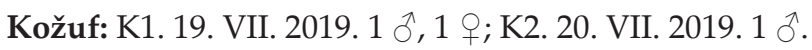

22. Drusus vernonensis Malicky, 1989

Material examined:

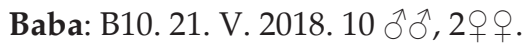

Literature records:

Baba: WARINGER et al. (2016): Reported from a tributary of Caparska Reka River in larval and adult stage.

Genus: Limnephilus Leach, 1815

23. Limnephilus affinis Curtis, 1834

Material examined:

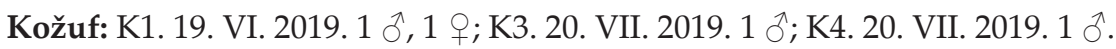

Note: new for Kožuf Mountain 
24. Limnephilus flavicornis (Fabricius, 1787)

Material examined:

Kožuf: K1. 20. VII. 2019. 1 ఫొ.

Note: New to the fauna of R. North Macedonia

25. Limnephilus lunatus Curtis, 1834

Material examined:

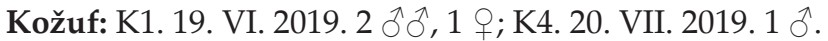

Note: new for Kožuf Mountain

26. Limnephilus bipunctatus Curtis, 1834

Material examined:

Baba: B10. 21. V. 2018. 1 ๙ึ่.

Note: new for Baba Mountain

Genus: Potamophylax Wallengren, 1891

27. Potamophylax pallidus (Klapalek, 1899)

Material examined:

Kožuf: K3. 20. VII. 2019. 1 ఫొ.

Literature records:

Kožuf: OlÁH \& KovÁCS (2013): Lake and open brook in alpine grassland towards Ski Kožuf.

28. Potamophylax lemezes Olah \& Graf, 2013

Material examined:

Kožuf: K1. 19. VI. 2019. 1 9.

Baba: B5. 20. VI. 2019. 2 ええ.

Note: new for Kožuf and Baba mountains

Genus: Micropterna Stein, 1873

29. Micropterna caesareica Schmid, 1959

Material examined:

Kožuf: K1. 19. VI. 2019. 2 ఏో

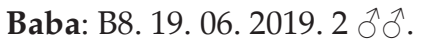

Note: new for Kožuf and Baba mountains

30. Micropterna sequax McLachlan, 1875

Material examined:

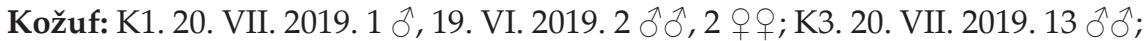
K4. 20. VII. 2019. $2 \widehat{\jmath}$.

Baba: B9. 19. 06. 2019. 1 ऽ.

Note: new for Kožuf and Baba mountains

\section{Genus: Stenophylax Kolenati, 1848}

31. Stenophylax meridiorientalis Malicky, 1982

Material examined:

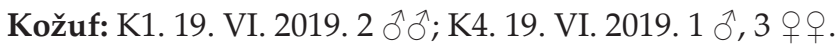

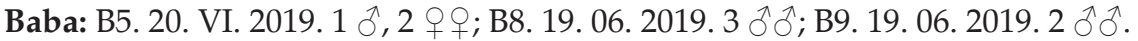

Literature records:

Baba: Olah \& Kovacs (2013): Open brrok at ski station in Nižepole.

Note: new for Kožuf Mountain 
Family: UENOIDAE Iwata, 1927

Genus: Thremma McLachlan, 1876

32. Thremma anomalum McLachlan, 1876

Material examined:

Kožuf: K4. 19. VI. 2019. 4 ठิઝે.

Baba: B5. 20. VI. 2019. 4 ฮิ ฮิ.

Literature records:

Baba: BotoşĂneAnu (1960): Springs in the alpine area and by the river in Capari village; Radovanović (1943): Upper part of Trnovska Reka river.

Note: new for Kožuf Mountain

Family: ODONTOCERIDAE Wallengren, 1891

Genus: Odontocerum Leach, 1815

33. Odontocerum albicorne (Scopoli, 1763)

Material examined:

Kožuf: K3. 20. VII. 2019. 1 ð̊.

Note: new for Kožuf Mountain

Family: GOERIDAE Ulmer, 1903

Genus: Silo Curtis, 1830

34. Silo pallipes Fabricius, 1781

Material examined:

Baba: B6. 20. VI. 2019. 2 ๙ึ, 1 ․

Literature records:

Baba: Radovanović (1943): Upper part of Trnovska Reka river and Rotinska Reka river; Slavevska-Stamenković and Hinić (unpublished data): Collected in larval stage from Brajchinska Reka river above the turbine room of SHPP Brajcinska 1.

Family SERICOSTOMATIDAE Stephens, 1876

Genus: Oecismus McLachlan, 1876

35. Oecismus mucidus McLachlan, 1876

Material examined:

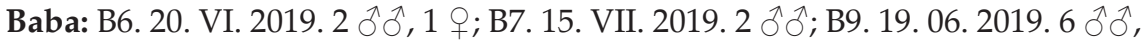
1 ㅇ.

Literature records:

Baba: Botoşăneanu (1960): Main brook towards Bitola (1800 - $2500 \mathrm{~m}$ asl); Radovanović (1943): Rotinska Reka river.

Family: BERAEIDAE Wallengren, 1891

Genus: Beraea Stephens, 1836

36. Beraea pullata (Curtis, 1834)

Material examined:

Kožuf: K2. 20. VII. 2019. 1 ○ૈ.

Literature records:

Kožuf: OláH \& Kovács (2013): Pond and open brook in alpine grassland towards Ski Kožuf. 


\section{DISCUSSION}

Literature data about caddisfly fauna from Kožuf Mountain are scarce, with only eight species reported in the last decade (OláH et al., 2013; OláH \& Kovács 2013, 2014; Previšić et al., 2014). Our investigation significantly contributes to the inventory of the caddisfly fauna as we found 27 taxa, of which 22 are recorded for the first time for Kožuf Mountain. Three of the previously known species (OLÁH \& KovÁcs 2013, 2014; Previšić et al., 2014) were confirmed during our study, while the following five were not found: Chaetopteroides tunik, Hydropsyche peristerica Botosaneanu \& Marinković-Gospodnetić, 1968, Notidobia nekibe Klapálek, 1903, Oecismus monedula (Hagen, 1859) and Tinodes unidentatus Klapálek, 1894. According to literature and our new faunistic data, 31 taxa in total are currently known from Kožuf Mountain, including one Drusus Stephens, 1837, a species currently identified only to generic level. This species is closely related to Drusus vernonensis according to the initial morphological comparison and the description is underway following collection of more specimens.

Limnephilus flavicornis (Fabricius, 1787) collected near the brook in the forest zone (K1) on Kožuf Mountain is recorded for the first time in R. North Macedonia and thus is a new species for Macedonian fauna. It has been recently reported from Kosovo and the rest of the Balkan Peninsula apart from Albania (Iвrahimi et al., 2019). In other neighboring and nearby countries, it is a rare species and is only known from few localities (Neu et al., 2018). According to Graf et al., (2008) the preferred stream zonation for this species are littoral zones and then to a lesser degree the epipotamal and metapotamal zones. The altitude preference for L. flavicornis according to the same source was reported not to exceed 1000 meters and is exclusively related to submontane, collin and planar areas. However, as it was found recently in Kosovo (IвRAнimi et al., 2019) at $1598 \mathrm{~m}$ asl and during our investigation in Kožuf Mountain at $1580 \mathrm{~m}$ asl, we can conclude that this species inhabits much higher altitudes in Balkans than in Central and Western Europe.

The results of our investigation revealed the presence of a considerable number of rare species on Kožuf Mountain which are currently known only from one or few localities in the Republic of North Macedonia: Beraea pullata, Drusus biggutatus, Glossosoma klotho, Limnephilus affinis, Limnephilus flavicornis, Limnephilus lunatus, Micropterna caesareica, Micropterna sequax, Odontocerum albicorne, Plectrocnemia brevis, Potamophylax lemezes, Rhyacophila balcanica, Rhyacophila fischeri, Rhyacophila obtusa, Rhyacophila loxias, Rhyacophila polonica and Stenophylax meridiorientalis (Neu et al., 2018).

Among the rare species recorded on Kožuf Mountain especially interesting are the findings of Beraea pullata and Glossosoma klotho. Beraea pullata was recently recorded for the first time by an open brook in alpine grassland at $1660 \mathrm{~m}$ asl on Kožuf Mountain by OlÁH \& Kovacs (2014). Taking it into consideration that the species was also found during our investigation on an open brook in alpine grassland on $1808 \mathrm{~m}$ asl (K2), we can speculate that Kožuf Mountain still represents the only locality in the country where the species occurs. Although in some European countries such as Slovenia, B. pullata is widespread (IвrAhimi \& Kučinić, 2018), in most of the countries neighboring on R. North Macedonia it is considered very rare (e.g. IвrAhimi et al., 2016; IвRAHImi \& KuČinić, 2018). We presume that the sparse findings of this species in some of the Balkan countries are a consequence of the lack of inventories and it is probably to be expected from more localities in high altitudes. B. pullata is listed in the Polish Red List of Trichoptera (Data Deficient category; Buczynska 2008), is classi- 
fied as rare in France (SANTOul et al., 2005) and in the second category of endangerment of the Red List of Caddisflies of Berlin (Mey, 2005). It is also present in the Red List of Fauna of the Republic of Kosovo (Iвrahimi et al., 2018) in the category Data Deficient.

During our investigation on Kožuf Mountain we found Glossosoma klotho for the second time in R. North Macedonia. The species was described by MaLicky (2003) based on material from Greece, Macedonia and Montenegro. It is one of the rarest species of this genus in the Balkan Peninsula and besides its type locality in Greece (Peloponnese) and few other localities (Central Greece; Karaouzas \& Malicky, 2015), it is also known from single localities in Kosovo (Shar Mountains) (Ibrahimi et al., 2016), Albania (Delvinë district) (OlaH, 2010), R. North Macedonia (Radika River, Mavrovo) and Montenegro (Durdevica Tara) (Malicky, 2003; Ibrahimi et al., 2016). As the species was previously known only from Mavrovo, our finding in Kožuf Mountain expands its distribution in R. North Macedonia and the Balkans as well. The altitude where it was found during our research is the preferred altitude for this species from where most of the records derive, although in Albania it was found by OLAH (2010) in much lower altitudes (155 m asl).

Faunistical information from published data and our research on Kožuf Mountain reveal that ten species (Drusus botosaneanui, Glossosoma klotho, Potamophylax lemezes, Rhyacophila balcanica, Rhyacophila fischeri, Rhyacophila obtusa, Rhyacophila loxias, Notidobia nekibe, Hydropsyche peristerica Botosaneanu \& Marinkovic-Gospodnetic, 1968 and Tinodes unidentatus) are narrow range endemics of the Balkan Peninsula and of narrow adjacent areas. As for C. tunik described by OLÁH et al., (2013) from Kožuf Mountain and most probably the newly found Drusus species, collected during our investigation, they are endemics of Kožuf Mountain. Furthermore, in the stream where sampling stations $\mathrm{K} 2$ and $\mathrm{K} 4$ are located, over a distance of only few hundred meters we noted the interesting phenomenon of four Drusus species living in sympatry: Drusus botosaneanui, Drusus biggutatus, Drusus discolor and Drusus sp. This suggests that favorable and diverse habitats of this area have served as glacial refugia for caddisflies in general and especially for microhabitat specialist species such as those belonging to the subfamily Drusinae (VITEceK et al., 2015a).

The review of literature data shows that 41 caddisfly species inhabit Baba Mountain (Radovanović, 1943; Botoşăneanu, 1960; Botosaneanu \& Marinković-GospodNetić 1966; Š́apkarev, 1997; OláH, 2010; OláH \& Kovács, 2013; PrevišIć et al., 2014; OlÁH et al., 2014, 2017, 2018, 2019; WARINGER et al., 2016). In the frame of our research on Baba Mountain we found 18 species, of which 8 are recorded for the first time from Baba Mountain and the presence of ten previously known species was confirmed: Drusus vernonensis Malicky, 1989, Drusus discolor (Rambur, 1842), Oecismus mucidus McLachlan, 1876, Philopotamus montanus (Donovan, 1813), Rhyacophila tristis Pictet, 1834, Rhyacophila nubila Zetterstedt, 1840, Stenophylax meridiorentalis Malicky, 1982, Silo pallipes Fabricius, 1781, Polycentropus flavomaculatus Pictet, 1834, and Thremma anomalum McLachlan, 1876. In total, 49 species are currently known from Baba Mountain based on literature records and our current research data.

The following species found during our investigation at Baba Mountain are quite rare in R. North Macedonia and are known currently only from one or few localities: Brachycentrus montanus, Drusus vernonensis, Limnephilus bipunctatus, Micropterna caesareica, Micropterna sequax, Oecismus mucidus, Polycentropus flavomaculatus, Potamophylax 
lemezes, Rhyacophila laevis, Rhyacophila nubila, Silo pallipes and Stenophylax meridiorentalis. Three species amongst them are found in Republic of North Macedonia only on Baba Mountain: Drusus vernonensis, Oecismus mucidus and Silo pallipes.

Drusus vernonensis was found during our investigation in a brook on the edge of the forest zone (B10) on Baba Mountain, near the tributary of Caparska Reka River where a few years ago it was collected by WARINGER et al. (2016). Beside this locality it is only known from the type locality in Mount Vernon in Greece, near the border area with Republic of North Macedonia (MaLIcky, 1989). It belongs to the discophorus species complex (OlÁH et al., 2017), which comprises microendemic species in the Balkan Peninsula and like other species of this complex it usually inhabits spring areas of higher altitudes.

Oecismus mucidus was reported previously from Baba Mountain nearby Bitola (BotoşĂNEANu, 1960) and has not been reported again until now. We found it in three sampling stations on Baba Mountain (B6, B7, B9) which shows that it is quite widespread in this mountain, with stable populations. O. mucidus is an endemic species of the Balkan Peninsula currently known only from Greece, Macedonia, and Kosovo (MALICKY, 2004; IBRAHImi \& VehaPI, 2017) associated with the upper reaches of unpolluted streams and rivers (e.g., Graf et al., 2008).

The first data for the presence of Silo pallipes in the R. North Macedonia were published about seventy years ago, when Radovanović (1943) found this species in the rivers Rotinska and Trnovska on Baba Mountain. Recently, Slavevska-Stamenković and Hinić (unpublished data) collected the species in the larval stage from Brajchinska Reka River above the turbine room of SHPP Brajcinska 1. During our research on Baba Mountain the adults of S. pallipes were collected on Stanisar Reka River below the intake of SHPP Brajcino 2. Thus, the finding of the species nowadays suggests steady populations of the species in this area. Additionally, results of this study contribute to knowledge about distribution of the species on Baba Mountain. Among the rare species registered on Baba Mountain, Rhyacophila laevis was found at a small brook on Rzanska Reka River (B5) which represents the second finding for Republic of North Macedonia. Recently, it was recorded for the first time in the country in the spring of Strezimirska Reka River in Mavrovo (Kučinić et al., 2016). R. laevis is known from most part of Europe but is not widespread in the Balkan Peninsula, from where it is known only from few localities (Iвrahimi et al., 2012).

The following 14 species found during our investigation or known from previous literature records in Baba Mountain are narrow range endemics of the Balkan Peninsula and of narrow adjacent areas: Chaetopteryx stankovici Marinkovic-Gospodnetic, 1966, Crunoecia monospina Botosaneanu, 1960, Drusus botosaneanui Kumanski, 1968, Drusus macedonicus Schmid, 1956, Drusus vernonensis, Drusus tenellus (Klapalek, 1898), Hydropsyche peristerica, Micrasema sericeum Klapalek, 1902, Oecismus mucidus, Potamophylax goulandriorum Malicky, 1974, Psilopteryx montanus Kumanski, 1968, Rhyacophila loxias Schmid, 1970, Rhyacophila balcanica Radovanović, 1953, Wormaldia kimminsi Botosaneanu, 1960. Recent research by OlÁH et al. (2018) resulted in the description of a new caddisfly species Agaphyalax balcanicus, from the spring area of Caparska Reka at $1952 \mathrm{~m}$ asl. The species is an endemic of Baba Mountain.

In conclusion, this paper summarizes faunistical information from both published and unpublished data concerning the caddisfly fauna of the Kožuf and Baba mountains and reports the first record of Limnephilus flavicornis from the country. Overall, 
the findings of still undescribed species and new species for the country, as well as endemic and rare species, indicate that Kožuf and Baba mountains are very important habitat areas for caddisfly fauna. Our results highlight the necessity of new surveys in the area in order to assess the overall biodiversity of this aquatic insect group and to evaluate the population status or extinction rates of Trichoptera species according to IUCN criteria. The data obtained could be useful for selection of the regions of Kožuf and Baba mountains that are of high conservation values, in which effective protection measures should be applied.

Received November 16, 2020

\section{REFERENCES}

Arsov, G., 1991: Taxonomical and biocenological analyses and altitude distribution of the larval caddisfly fauna of Zrnovska Reka river. Master thesis. Skopje. p. 1-148. (In Macedonian)

Bilalli, A., Ibrahimi, H. \& Musliu, M., 2018: First records of the caddisfly fauna (Insecta: Trichoptera) from the Karadak Mountains, Western Balkans. Natura Croatica 27(1), 143-151.

Bilalli, A., Ibrahimi, H., Musliu, M., Gashi, A., Grapci-Kotori, L., Slavevska-Stamenković, V. \& Geci. D., 2019: First record of Chaetopteroides kosovarorum Ibrahimi \& Oláh, 2013 (Insecta: Trichoptera) from the Republic of North Macedonia. Ecologica Montenegrina 23, 34-39.

Botoşăneanu, L., 1960: Trichoptères de Yougoslavie recueillis en 1955 par le Dr. F. Schmid. Deutsche Entomologische Zeitschrift 7(3), 261-293.

Botosaneanu, L. \& Marinković-Gosponnetić, M., 1966: Contribution à la connaissance des Hydropsyche du groupe fulvipes-instabilis. Etude des genitalia mâles [Trichoptera]. In Annales de Limnologie-International Journal of Limnology 2(3), 503-525.

Buczynska, E., 2008: The caddisflies (Trichoptera) of springs in the Roztocze region (south-eastern Poland). Annales Universitatis Mariae Curie-Sklodowska Lublin-Polonia 63(2), 13-22.

Graf, W., Murphy, J., Dahl, J., Zamora-Munoz, C. \& Lopez-Rodriguez, M. J., 2008: Distribution and ecological preferences of European freshwater organisms. Pensoft Publishing. Volume 1. Trichoptera (Vol. 1).

Ibrahimi, H. \& Kučinić, M., 2018: First record of Beraea pullata (Curtis, 1834) (Insecta, Trichoptera) for Albania. Acta Entomologica Slovenica 26(1), 83-88.

Iвrahimi, H. \& Vehapi, V., 2017: Contribution to the knowledge of the caddisfly fauna (Insecta: Trichoptera) of the Sharr Mountains in Kosovo. Journal of the Kansas Entomological Society 90(4), 283-290.

Ibrahimi, H., Kučinić, M., Gashi, A., Grapci-Kotori, L., Vučković, I. \& Cerjanec, D., 2012: The genus Rhyacophila Pictet, 1834 (Insecta: Trichoptera) in Kosovo. Aquatic Insects 34(sup1), 23-31.

Iвrahimi, H., Gashi, A. \& Kotori, L. G., 2016: First records of three rare species of the genus Glossossoma Curtis, 1834 (Insecta: Trichoptera) from the Republic of Kosovo. Journal of the Entomological Research Society 18(2), 79-83.

Ibrahimi, H., Gashi, A., Rexhepaj, D., Etemi, F. Z., Grapci-Kotori, L., Feher, Z., Bino, T., Jelaka, L. S., Mesaros, G. \& Theou, P., 2019: Red Book of Fauna of the Republic of Kosovo - Libri i Kuq i Faunës së Republikës së Kosovës. Ministria e Mjedisit dhe Planifikimit Hapësinor / Ministry of Environment and Spatial Planning. 405 p.

Ibrahimi, H., Grapci-Kotori, L., Bilalli, A., Qamili, A. \& Schabetsberger, R., 2019: Contribution to the knowledge of the caddisfly fauna (Insecta: Trichoptera) of Leqinat lakes and adjacent streams in Bjeshkët e Nemuna (Kosovo). Natura Croatica: Periodicum Musei Historiae Naturalis Croatici 28(1), 35-44.

Illies, J., 1978: Limnofauna Europaea. A Checklist of the Animals Inhabiting European Inland Waters, with an Account of their Distribution and Ecology. 2nd Edition. Gustav Fischer Verlag, Stuttgart. $552 \mathrm{pp}$.

Karaouzas, I. \& Malicky, H., 2015: New faunistic records of Trichoptera in Greece. Braueria, 42, 13-20. 
Kučinić M., Previšić, A., Mihoci, I., Krpač, V., Žıvić, I., Stojanović, K., Vojvoda, A. M. \& Katušić, L., 2016: Morphological features of larvae of Drusus plicatus Radovanović (Insecta, Trichoptera) from the Republic of Macedonia with molecular, ecological, ethological, and distributional notes. ZooKeys 598, 75.

Kumanski, K., 1985: Trichoptera, Annulipalpia. Fauna Bulgarica 15. Bulgarska Akademi na Naukite, Sofia. 243 pp.

KumAnski, K., 1988: Fauna Bulgarica. 19. Trichoptera, Integripalpia. Bulgarian Academy of Sciences, Sofia. 354 pp.

Kumanski, K., 1997: Contributions to the caddisfly fauna (Trichoptera) of the central-western part of the Balkan Peninsula. Lauterbornia 31, 73-82.

Kumanski, K. \& Malicky, H., 1999: A survey of the genus Potamophylax Wallengren 1891 in the Balkan Peninsula, with description of two new species (Trichoptera: Limnephilidae). Braueria 26, 27-30.

Malicky, H., 1989: Ein neuer Drusus aus Nord-Griechenland (Trichoptera, Limnephilidae). Entomologische Zeitung 99, 303-304.

Malicky, H., 2003: Bemerkungen über griechische Glossosoma-Arten (Trichoptera, Glossosomatidae). Braueria 30, 39-40.

Malicky, H., 2004: Atlas of European Trichoptera-Springer, Dordrecht. 359 pp.

Mey, W., 2005: Rote Liste und Gesamtartenliste der Köcherfliegen (Trichoptera) von Berlin. In: Der Landesbeauftragte Fur Naturschutz und Landschaftspflege / Senatsverwaltung Fur Stadtentwicklung (Hrsg.): Rote Listen der gefährdeten Pflanzen und Tiere von Berlin. CD-ROM.

Morse, J. C. (ed.), 2020: Trichoptera World Checklist Database Search, Checklist. http:/ / entweb.clemson.edu/database/trichopt/index.htm (Accessed 6 February 2020).

Neu, P. J., Malicky, H., Graf, W. \& Schmidt-Kloiber, A., 2018: Distribution atlas of European trichoptera. ConchBooks.

OLÁH, J., 2010: New species and new records of Palearctic Trichoptera in the material of the Hungarian Natural History Museum. Annales historico-naturales Musei nationalis hungarici 102, 65-117.

OlÁH, J., 2011: New species and records of Balkan Trichoptera. Folia Historico Naturalia Musei Matraensis 35, 111-121.

OláH, J. \& KovÁcs, T., 2013: New species and records of Balkan Trichoptera II. Folia Historico Naturalia Musei Matraensis 37, 109-121.

OlÁH, J. \& KovÁcs, T., 2014: New species and records of Balkan Trichoptera III. Folia Historico Naturalia Musei Matraensis 38, 97-131.

Olah, J., Andersen, T., Chvojka, P., Coppa, G., Graf, W., Ibrahimi, H., Lodovici, O., Previšić, A. \& VAlle, M., 2013A: The Potamophylax nigricornis group (Trichoptera, Limnephilidae): resolution of phylogenetic species by fine structure analysis. Opuscula Zoologica Instituti Zoosystematici et Oecologici Universitatis Budapestinensis 44(2).

Oláh, J., Ibrahimi, H. \& Kovács, T., 2013в: The genus Chaetopteroides (Trichoptera, Limnephilidae) revised by fine structure analysis of parameres. Folia Historico Naturalia Musei Matraensis 37, 93-108.

Oláh, J., Chvojka, P., Coppa, G., Graf, W. \& Ibrahimi, H., 2014: The genus Allogamus Schmid, 1955 (Trichoptera, Limnephilidae): revised by sexual selection-driven adaptive, non-neutral traits of the phallic organ. Opuscula Zoologica (Budapest) 45(1), 33-82.

Oláh, J., Chvojka, P., Coppa, G., Godunko, R. J. \& Lodovici, O., 2015: Limnephilid taxa revised by speciation traits: Rhadicoleptus, Isogamus, Melampophylax genera, Chaetopteryx rugulosa, Psilopteryx psorosa species groups, Drusus bolivari, Annitella kosciuszkii species complexes (Trichoptera: Limnephilidae). Opuscula Zoologica (Budapest) 46(1), 3-117.

Oláh, J., Beshrov, S., Chvojka, P., Ciubuc, C. \& Coppa, G., 2017: Revision of Drusinae subfamily (Trichoptera, Limnephilidae): divergence by paraproct and paramere: speciation in isolation by integration. Opuscula Zoologica (Budapest) 48(S1), 3-228.

OláH, J., Kovács, T. \& Ibrahimi, H., 2018: Agaphylax, a new limnephilid genus (Trichoptera) from the Balkan: Lineage ranking by adaptive paramere. Opuscula Zoologica (Budapest) 49(1), 77-89.

Oláh, J., Trond, A., Stoyan, B., Coppa, G., Ruiz-Garcia, A. \& Johanson, K. A., 2019: Revision of European Wormaldia species (Trichoptera, Philopotamidae): Chimeric taxa of integrative organisation. Opuscula Zoologica (Budapest) 50(1), 31-85. 
Pavlovski, T., 1984: Two new rare species for the caddisfly fauna of R. Macedonia. Annuarie Facultè des Sciences Naturelles de 1' Universitè "Kiril et Metodij"- Skopje. Vol 37-38, 11-115. (In Macedonian).

Pavlovski, T., 1991: Structure, dynamics and distribution of the caddisfly larval fauna of river Babuna. Special edition from Faculty of Biology - Skopje. p. 1-81. (In Macedonian).

Previšić, A., Schnitzler, J., Kučinić, M., Graf, W., Ibrahimi, H., Kerovec, M. \& Pauls, S., 2014: Microscale vicariance and diversification of Western Balkan caddisflies linked to karstification. Freshwater Science 33(1), 250-262.

Radovanović, M., 1935: Trichoptera Jugoslavije. Glasnik Zemaljskog muzeja u Bosni i Hercegovini u Sarajevu 47, 73-84.

Radovanović, M., 1943: Trichoptera of the Lake Ohrid and surrounding area. SANU, Special edition. Proceedings of Ohrid 1, 3-46.

Radovanović, M., 1953: Prilog poznavanju Trichoptera Balkanskog poluostrva, prvenstveno u pećinama i planinskim jezerima. Glas SAN 210(7), 11-38.

Rimcheska, B., Slavevska-Stamenković, V., Ibrahimi, H., Smiljkov, S., Ristovska, M. \& Paunović, M., 2015: First Record of the Genus Helicopsyche von Siebold, 1856 (Trichoptera: Helicopsychidae) from the Republic of Macedonia. Acta Zoologica Bulgarica 67(3), 443-446.

Santoul, F., Figuerola, J., Mastrorillo, S. \& Cereghino, R., 2005: Patterns of rare fish and aquatic insects in a southwestern French river catchment in relation to simple physical variables. Ecography 28, 307-314.

Slavevska-Stamenković, V., Rimcheska, B., Vidinova, Y., Tyufekchieva, V., Ristovska, M., Smiljkov, S., Paunović, M. \& Prelić, D., 2016: Contribution to the knowledge of Ephemeroptera, Plecoptera and Trichoptera species from Republic of Macedonia: Distribution and conservation implication. Acta Zoologica Bulgarica 68(2), 199-206.

Stojmilov, A., 2011: Geographical characteristics of Republic of Macedonia. Book I, 35-58.

ŠAPKAREv, J., 1997: Macrofauna of glacial lakes on Pelister (Baba Mt.). Annuarie Facultè des Sciences Naturelles de 1' Universitè "Kiril et Metodij"- Skopje Vol. 50, x-x. (In Macedonian).

Vitecek, S., Graf, W., Previšić, A., Kučinić, M., Oláh, J., Bálint, M., Keresztes, L., Pauls, S. U. \& WARIngER, J., 2015a: A hairy case: The evolution of filtering carnivorous Drusinae (Limnephilidae, Trichoptera). Molecular phylogenetics and evolution 93, 249-260.

Vitecek, S., Kučinić, M., Oláh, J., Previšić, A., Bálint, M., Keresztes, L., Waringer, J., Pauls, S. U. \& W. Graf, W., 2015b: Description of two new filtering carnivore Drusus species (Limnephilidae, Drusinae) from the Western Balkans. ZooKeys 513, 79.

Vitecer, S., Previšić, A., Kučinić, M., Bálint, M., Keresztes, L., Waringer, J., Pauls, S. U., Malicky, H. \& Graf, W., 2015c: Description of a new species of Wormaldia from Sardinia and a new Drusus species from the Western Balkans (Trichoptera, Philopotamidae, Limnephilidae). ZooKeys 496, 85.

Waringer, J., Graf, W., Balint, M., Kučinić, M., Pauls, S. U., Previšić, A., Keresztes, L., Ibrahimi, H., Živić, I., BJelanović, K. \& Krpač, V., 2015: Larval morphology and phylogenetic position of Drusus balcanicus, Drusus botosaneanui, Drusus serbicus and Drusus tenellus (Trichoptera: Limnephilidae: Drusinae). European journal of entomology 112(2), 344.

Waringer, J., Previšić, A., Kučinić, M., Graf, W., Vitecer, S., Keresztes, L., Bálint, M. \& Pauls, S. U., 2016: Larval morphology of the Western Balkans endemic caddisflies Drusus krusniki Malicky 1981, D. vernonensis Malicky 1989, and D. vespertinus Marinković 1976 (Trichoptera, Limnephilidae, Drusinae). Zootaxa 4083(4), 483. 